\title{
Corrosion Behavior of Cenosphere Reinforced Al7075 Metal Matrix Composite -An Experimental Approach
}

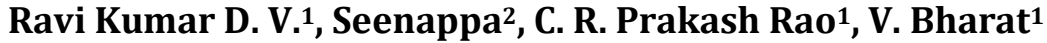 \\ ${ }^{1}$ Department of Mechanical Engineering, Global Academy of Technology, Bengaluru, India \\ ${ }^{2}$ Department of Mechanical Engineering, Government Engineering College, Ramanagara, India \\ Email: ravikumardv@gat.ac.in
}

How to cite this paper: Ravi Kumar D. V., Seenappa, Prakash Rao, C.R. and Bharat, V. (2018) Corrosion Behavior of Cenosphere Reinforced Al7075 Metal Matrix Composite-An Experimental Approach. Journal of Minerals and Materials Characterization and Engineering, 6, 424-437.

https://doi.org/10.4236/jmmce.2018.63030

Received: April 11, 2018

Accepted: May 22, 2018

Published: May 25, 2018

Copyright $\odot 2018$ by authors and Scientific Research Publishing Inc. This work is licensed under the Creative Commons Attribution International License (CC BY 4.0).

http://creativecommons.org/licenses/by/4.0/

(c) (i) Open Access

\begin{abstract}
Aluminum-based metal matrix composites (MMCs) are considered in several technological applications owing to their enhanced mechanical properties when compared with monolithic metals. Research on the mechanical properties MMCs was done by many researchers; however in depth study on the oxidation behavior of cenosphere, reinforced MMCs are required, since the application of Aluminum-based MMCs is extensively used in applications like automobile, navigation and aviation, where the demand on light weight corrosion resistance material is very much required. In the present work varied compositions of Al7075 grade Aluminum-cenosphere composites use liquid metallurgy route adopting stir casting approach. The experimental study was aimed at experimental investigations of developed composites under different corrosive environments. The corrosion tests were carried out as per ASTM standards. Salt spray test using $\mathrm{NaCl}$ was carried out as per ASTM B117 and immersion tests using $\mathrm{NaCl}$ and $\mathrm{NaOH}$ as corrodents were carried out by following ASTM G31 standards. The results obtained from the tests revealed that as increase in weight $\%$ of reinforcement, corrosion resistance increases up to $7.5 \%$ reinforcement, and further the corrosion resistance decreases marginally. Solution heat treated samples exhibited higher resistance to oxidation than cast samples in all corrosive environments. The SEM images show the presence of micro cracks and occurrence of pitting corrosion on the corrosion tested specimens.
\end{abstract}

\section{Keywords}

Al7075, Cenosphere, Metal Matrix Composites, $\mathrm{NaCl}, \mathrm{NaOH}$, Salt Spray Test, Corrosion Wear 


\section{Introduction}

The increased strength to weight ratio of MMCs directs its usage in the manufacture of automobile parts, consumer oriented products and also for spare parts used in the machineries. Research work on casting and characterization of MMCs was done by many and articles were published related to this subject. The research work carried out by previous investigations on fabrication of aluminium cenosphere composites was done by following the naval method known as stir casting [1]-[7]. The hardness of the Aluminum MMCs increased with the percent addition of the reinforcement. The bonding of the reinforcement with the matrix material was found significant, when sintering process was done at $600^{\circ} \mathrm{C}[8]$. The even dispersion of the hollow spheres in the matrix material was observed in the microstructural analysis [9] [10] [11]. Macro \& microstructure measurements revealed almost uniform distribution of reinforcement particulates even at the central part of the castings [12]. Increase in the rate of oxidation with increased temperature and the increase in the concentration of the corrosion media were observed [13], degradation of the composites was minimized by using calcinated fly ash, and also control forming of $\mathrm{Mg}_{2} \mathrm{Si}$ becomes a clear cut parameter which eliminates aggressive confined oxidation [14]. Madakson P. B et al. observed in their research work that, Al7075 rusted sooner in $1.0 \mathrm{M} \mathrm{HCl}$ when compared to $1.0 \mathrm{M} \mathrm{NaOH}$ solution and the corrosion rate of Aluminum alloy was reduced by anodizing in both [15]. The experimental results of corrosion test revealed that higher corrosion resistance during testing of as cast samples when compared to laser re melted samples and also the boundaries between aluminium rich phase and silicon particles were observed during microscopic analysis [16]. The results of research work showed the importance of shot-peening process on oxidation fatigue properties. The compressive residual stresses induced in the surface layer initiated the fatigue cracks, and also the improvement in fatigue life of structural elements made of high-strength aluminium alloys [17]. Weight loss for both Alclad and extruded shapes was the lowest in urban atmosphere and the highest in industrial atmosphere. Moreover, the back face of Alclad 7075 and 2024 was subjected to pitting corrosion in coastal atmosphere. The pitting corrosion was prominent on the front face of Alclad in urban and industrial atmospheres [18]. The observations of immersion corrosion tests revealed that the weight loss of MMCs is due to the rapid corrosion resulted by pit formation near the reinforcement and matrix interface [19]. Zinc aluminum based MMCs are ideal for the high wear resistance applications [20]. The results of comparative study of T6 treatment, RRA treatment and T616 treatments are proven that T616 treatments increase the strength as well as corrosion resistance of the Al7075 grade aluminum alloy [21]. Pitting corrosion found higher on AK12 alloy reinforced with 9\% fly ash of 75 - 100 microns particle size when compared to AK12 alloy [22]. The bottom portion of the specimen was subjected to higher corrosion which was subjected to fatigue and tension tests [23]. Reduction in corrosion resistance of aluminum (12\% silicon) 
containing $15 \%$ fly ash composite observed with increase of fly ash content [24].

The above review revealed that a less research work was done on the effect of percent filler on corrosion resistance of solution heat treated Al7075-cenosphere composite. Thus, the research work was aimed at the experimental investigation of solution heat treated Al7075-cenosphere composite on corrosion properties using varied percent reinforcement.

\section{Materials and Method}

\subsection{Materials}

First, chemical composition Al7075 grade Aluminum alloy is presented in Table 1 , was selected as matrix material for the investigation. The hollow spheres consists of ceramic particles were the reinforcement used for the preparation of the composite material and the analysis report of the cenosphere is presented in $\mathrm{Ta}$ ble 2. The chemical composition of Al7075 alloy carried out using optical emission spectrometer BAIRD-DV6, and the chemical composition of cenosphere were carried out through ICP-OES, Perkin Elmer equipment.

\subsection{Separation of Cenosphere from Fly Ash}

Burning of coal in thermal power plant gives out fly ash containing maximum percentage of alumina and silica. The cenospheres are separated from the fly ash following flotation method, which are light in weight, inert and hollow spheres. The hollow globoid filled with a gas consisting of Silica and Alumina, which forms during combustion of coal. The properties of hollow spheres generally depend on the type of coal utilized during burning of coal.

\subsection{Production of Composites}

The Al7075 grade aluminum alloy as a matrix materials after verification of hardness, density and chemical composition, were cut into $30 \mathrm{~mm}$ length, consisting of a weight obtained as per rule of mixture were staked in the graphite crucible followed by melting process using induction furnace. The temperature of $200^{\circ} \mathrm{C}$ maintained in order to remove moisture content from the cenosphere particles. Simultaneously previously prepared permanent die casting mould of diameter $32 \mathrm{~mm}$ and length $350 \mathrm{~mm}$ were preheated before pouring the molten composite material. Upon attaining the melt temperature to about $690^{\circ} \mathrm{C}$

Table 1. Chemical composition of Al7075 alloy by weight \%.

\begin{tabular}{cccccccccc}
\hline Chemical composition & $\mathrm{Zn}$ & $\mathrm{Cu}$ & $\mathrm{Si}$ & $\mathrm{Fe}$ & $\mathrm{Mg}$ & $\mathrm{Cr}$ & $\mathrm{Mn}$ & $\mathrm{Ti}$ & $\mathrm{Al}$ \\
\hline $\mathrm{Wt} \%$ & 5.186 & 1.461 & 0.063 & 0.130 & 2.267 & 0.251 & 0.043 & 0.059 & Balance \\
\hline
\end{tabular}

Table 2. Chemical composition of cenosphere by weight $\%$.

\begin{tabular}{ccccccccc}
\hline Chemical composition & $\mathrm{SiO}_{2}$ & $\mathrm{Al}_{2} \mathrm{O}_{3}$ & $\mathrm{MgO}$ & $\mathrm{Fe}_{2} \mathrm{O}_{3}$ & $\mathrm{CaO}$ & $\mathrm{TiO}_{2}$ & $\mathrm{~K}_{2} \mathrm{O}$ & $\mathrm{Na}_{2} \mathrm{O}$ \\
\hline $\mathrm{Wt} \%$ & 58.29 & 32.75 & 1.2 & 2.9 & 0.5 & 1.27 & 1.29 & 0.25 \\
\hline
\end{tabular}


hexachloro ethane tablets were added in order to remove entrapped gases. The slag inclusions were removed from the melt upon completing degassing processes, further the preheated hollow spheres are introduced to the melt using stirring methodology. The melt temperature was maintained around $680^{\circ} \mathrm{C}$ during addition of preheated cenosphere particles of desired quantity as per rule of mixture. The composite melt was poured into the preheated permanent die casting mould after 30 minutes of stirring. After 24 hours, the cast composites were taken from the permanent die casting mould.

\subsection{Heat Treatment of Composite Material}

The cast composites with varied percent reinforcement were subjected to T6 heat treatment process includes solutionizing followed by aging process. The solutionizing process were done at $480^{\circ} \mathrm{C}$ and further quenched in cold water, followed by aging at $120^{\circ} \mathrm{C}$.

\section{Corrosion Test}

The corrosion tests were carried out following ASTM B117, ASTM G31 standards for corrosion test following salt spray method using varied percent $\mathrm{NaCl}$ and immersion corrosion test using $\mathrm{NaCl}$ and $\mathrm{NaOH}$ in order to simulate the corrosion which occurs naturally.

\subsection{Salt Spray Corrosion Test}

Salt spray corrosion test is a laboratory corrosion test method, generally used for evaluating of corrosion resistance of the materials, since it is an accelerated type of corrosion test, which corrodes the part of the specimen exposed to the corrosive environment. The salt spray test was carried out using neutral salt solution of $5 \mathrm{wt} \% \mathrm{NaCl}$ having $\mathrm{pH}$ value of 6.68 . The rate of corrosion was evaluated for 24 hours. The images of the samples before and after exposing to $5 \mathrm{wt} \% \mathrm{NaCl}$ corrosion environment are shown in Figure 1 and Figure 2.

\subsection{Immersion Corrosion Test}

The Immersion corrosion tests were carried out in two different corrosion

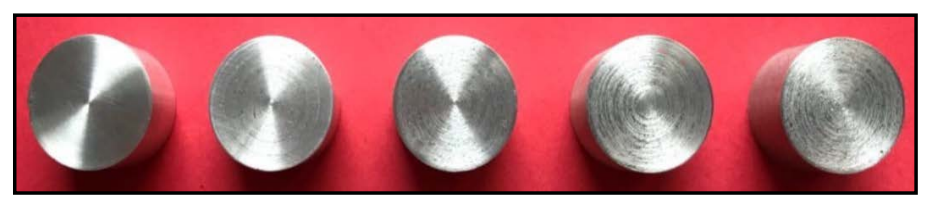

Figure 1. Samples before salt spray corrosion test.

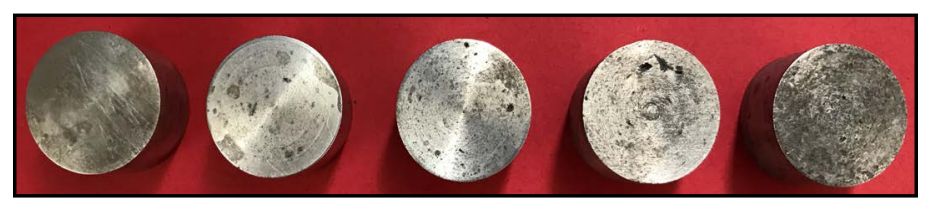

Figure 2. Samples after salt spray corrosion test. 
environments for both as cast and solution heat treated specimens. The specimens were prepared following standard procedures. The specimens for the test were machined to a size of diameter $30 \mathrm{~mm}$ and thickness $3 \mathrm{~mm}$, after which the surface of the samples were polished using abrasive papers of varied grit size. The specimens further subjected to the immersion corrosion test, weight loss for every specimens were evaluated as per ASTM G31 standards. Corrosion rate for every specimens were evaluated from the data obtained from weight loss measurements as per standard procedures.

\subsection{Corrosion Behavior in 5 wt\% NaCl Solution}

The immersion corrosion test on $5 \mathrm{wt} \% \mathrm{NaCl}$ solution was carried out for 30 days, at an interval of 5 days. Cleaning of the samples were carried out using standard cleaning reagent and then rinsed in distilled water, before immersing in the salt solutions of $5 \mathrm{wt} \% \mathrm{NaCl}$. The mass loss during immersion corrosion test in the $5 \mathrm{wt} \% \mathrm{NaCl}$ solution were evaluated for both as cast and solution heat treated specimens containing varied percent reinforcement. The images of the samples before and after immersion corrosion test on $5 \mathrm{wt} \% \mathrm{NaCl}$ solution are shown in Figure 3 and Figure 4.

\subsection{Corrosion Behavior in 0.1 M NaOH Solution}

The immersion corrosion experiment on $0.1 \mathrm{M} \mathrm{NaOH}$ solution was conducted between 12 to 96 hours, at an interval of 12 hours. Cleaning of the samples were carried out using standard cleaning reagent and then rinsed in distilled water, before immersing in $0.1 \mathrm{M} \mathrm{NaOH}$ solution. The mass loss as a result of the immersion corrosion on $0.1 \mathrm{M} \mathrm{NaOH}$ solution were evaluated for both as cast and solution heat treated specimens having varied percent reinforcement. The images of the samples before and after immersion corrosion test on $0.1 \mathrm{M} \mathrm{NaOH}$ solution are shown in Figure 5 and Figure 6.

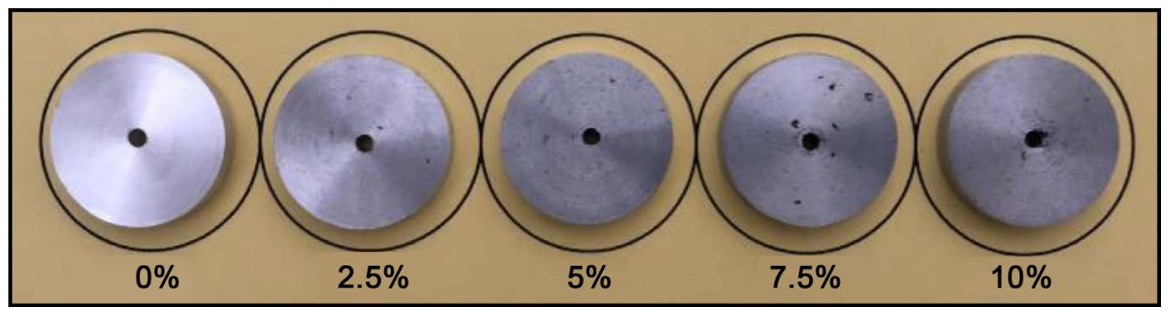

Figure 3. Specimens before immersion corrosion test on $5 \mathrm{wt} \% \mathrm{NaCl}$ solution.

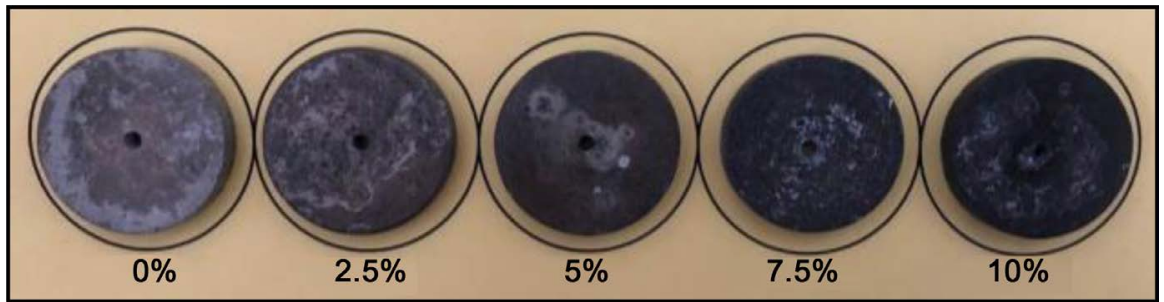

Figure 4.Specimens after immersion corrosion test on $5 \mathrm{wt} \% \mathrm{NaCl}$ solution. 


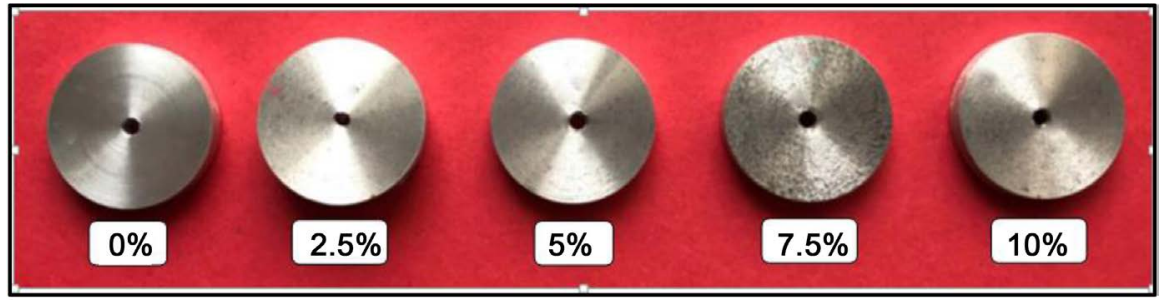

Figure 5. Specimens before immersion corrosion experiment on $0.1 \mathrm{M} \mathrm{NaOH}$ solution.

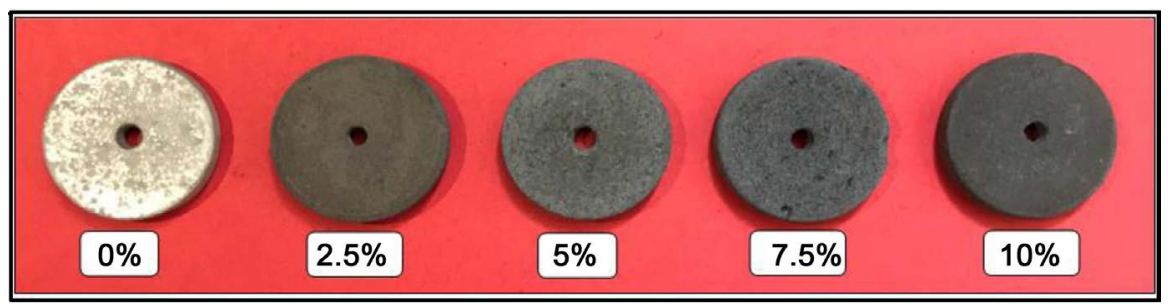

Figure 6. Specimens after immersion corrosion experiment on $0.1 \mathrm{M} \mathrm{NaOH}$ solution.

\subsection{Corrosion Behavior of Solution Heat-Treated Specimen}

Marginal reduction in corrosion rate and weight loss of the solution heat treated Al 7075 MMCs containing varied \% hollow sphere were observed. However, the corrosion rate and weight loss of the as cast specimens found higher than solution heat treated $\mathrm{Al} 7075 \mathrm{MMCs}$ containing varied \% hollow sphere. The slightly improved corrosion resistance is observed on solution heat treated specimens when compared to Al 7075 matrix. Layer of black film formation were seen on the specimen surface for both the as-cast and solution heat-treated samples. The reason for black film formation might be the hydroxyl chloride layer formation which could have eradicated further corrosion of the composites.

\section{Results \& Discussion}

\subsection{Salt Spray Corrosion Test}

The Salt spray corrosion test is preferred method used for evaluating corrosion resistance of the materials. Salt spray test is an accelerated type of corrosion test which produces corrosive attack on the specimen. The rate of corrosion of the specimens was evaluated after 24 hours of exposure in the salt spray environment. From Figure 7, it can be inferred, that the corrosion resistance of as cast composite material is lower than solution heat treated samples. From Figure 7, it can be inferred that as percent cenosphere increases the corrosion resistance of composite material increases till 7.5\% cenosphere, further the effect of addition of cenosphere increased weight loss for both as cast and solution heat treated increases marginally.

\subsection{Immersion Corrosion Test}

The immersion corrosion test is most recognized methods used for validating corrosion resistance of the materials. The immersion corrosion test were carried 
out on two different corrosion environments, that is, $5 \% \mathrm{NaCl}$ solution and 0.1 $\mathrm{M} \mathrm{NaOH}$ solution. The corrosion test was carried out for 30 days on $5 \% \mathrm{NaCl}$ solution, and weight loss as a result of corrosion test were measured after every 5 days. Figure 8 shows immersion corrosion test results of as cast composite materials, Figure 9, shows immersion corrosion test results of 3 hours solution treated composite materials, Figure 10, shows immersion corrosion test results of 5 hours solution treated composite materials. Figure 11, shows comparison of immersion corrosion test results after 30 days for as cast, 3 hour solution heat treated and 5 hours solution heat treated composite materials.

From, Figures 8-10, it can be inferred that, the variation of weight loss as a result immersion in the $\mathrm{NaCl}$ solution after 5 days - 30 days observed. Ascending order of weight loss observed on composite specimens up to 20 days exposure to the $\mathrm{NaCl}$, further it was found that the weight loss between 20 days and 30 days found negligible. From, Figure 11, it can be inferred that, the reduction of weight

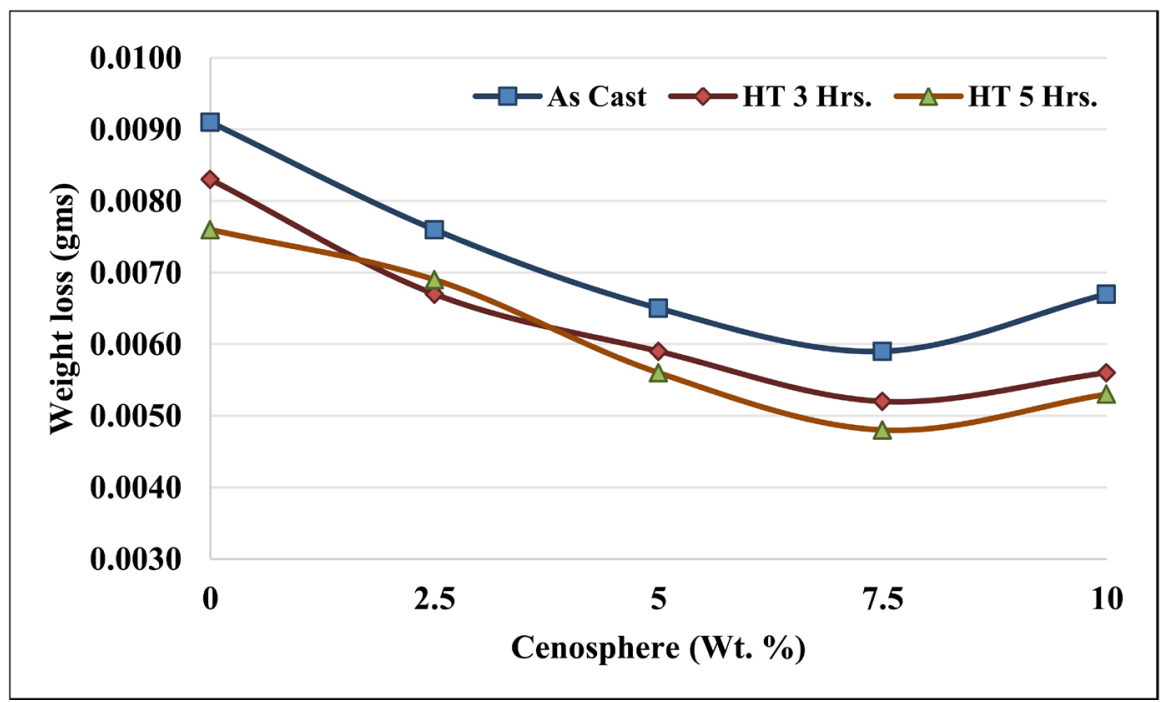

Figure 7. Salt spray corrosion test of composites.

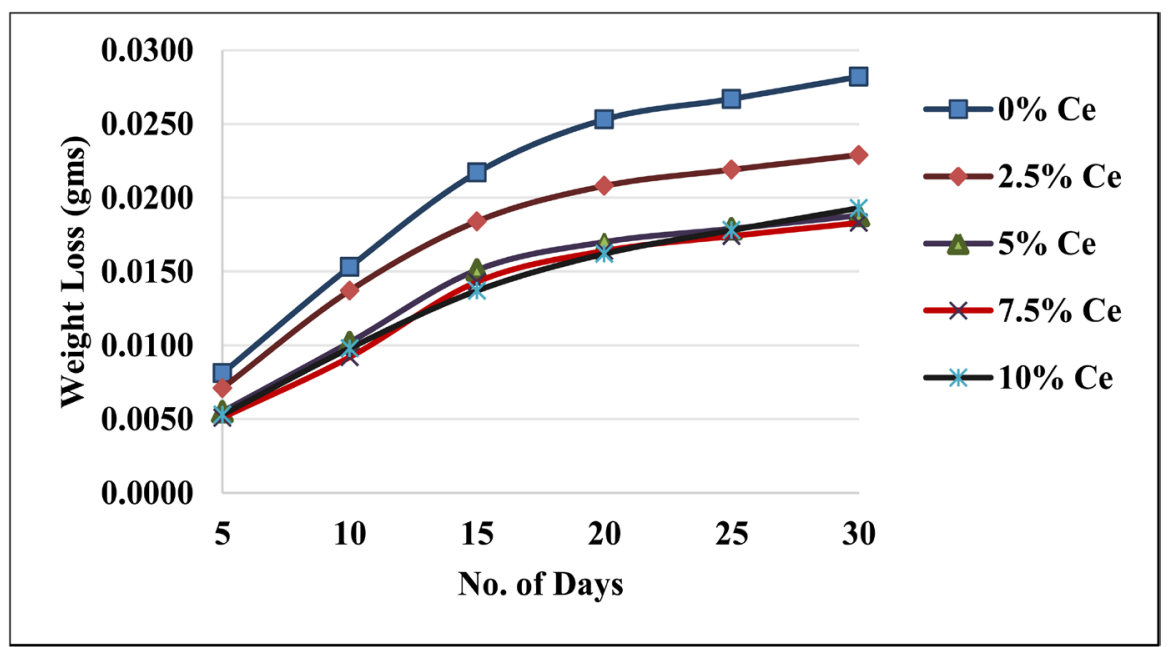

Figure 8. Immersion corrosion test of as cast samples of composites on $\mathrm{NaCl}$. 


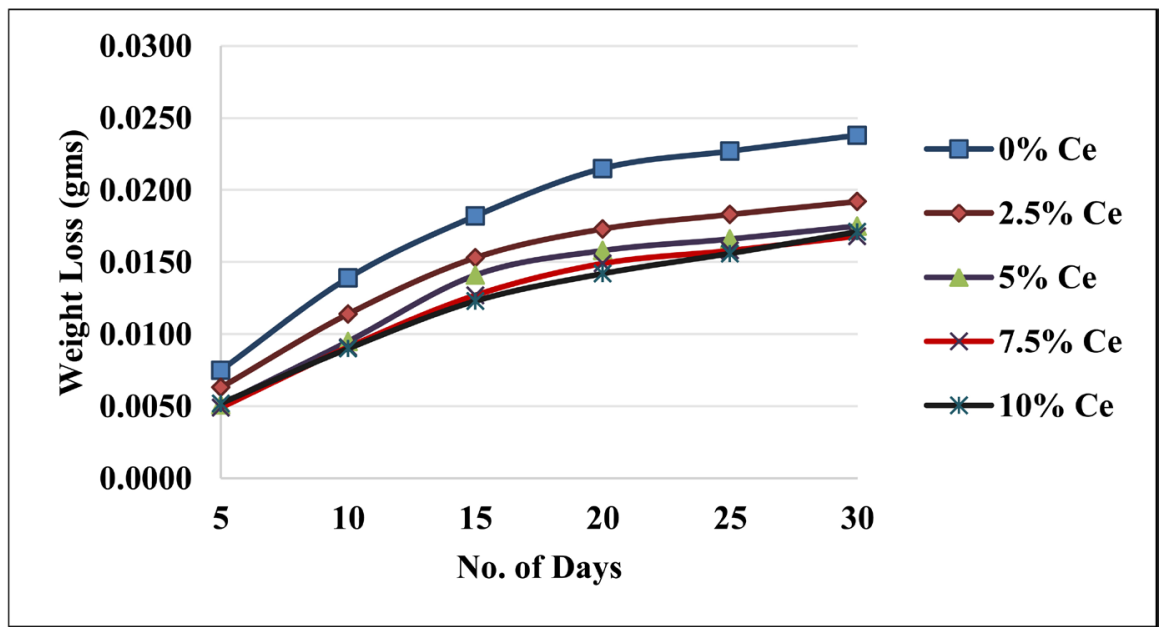

Figure 9. Immersion corrosion test of 3 hours solution heat treated samples of composites on $\mathrm{NaCl}$.

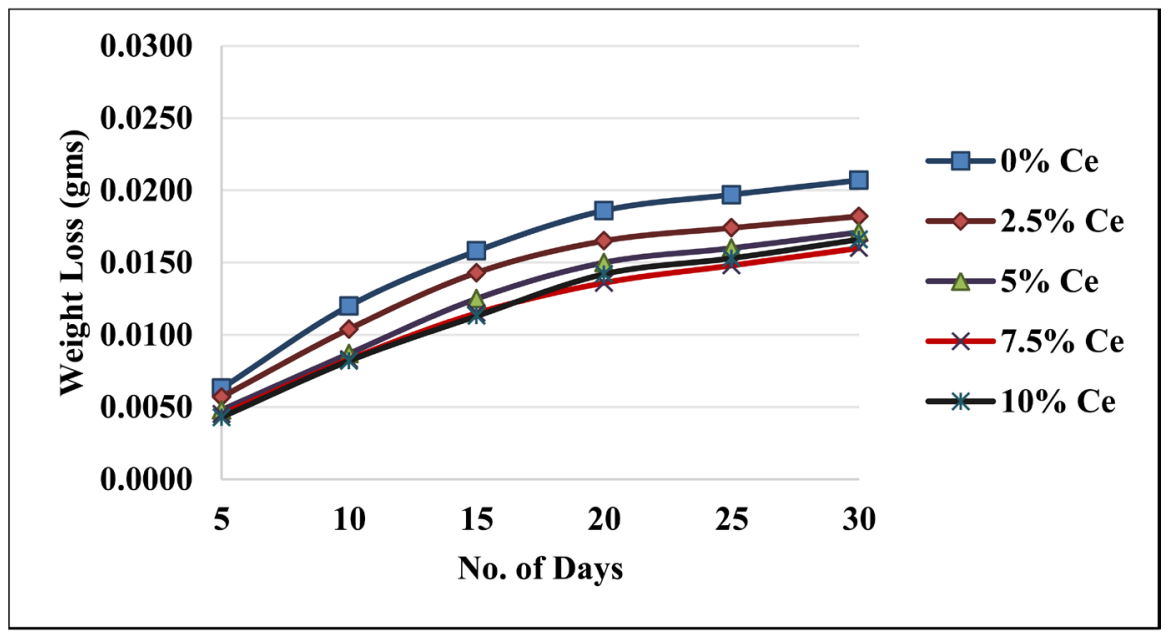

Figure 10. Immersion corrosion test of 5 hours solution heat treated samples of composites on $\mathrm{NaCl}$.

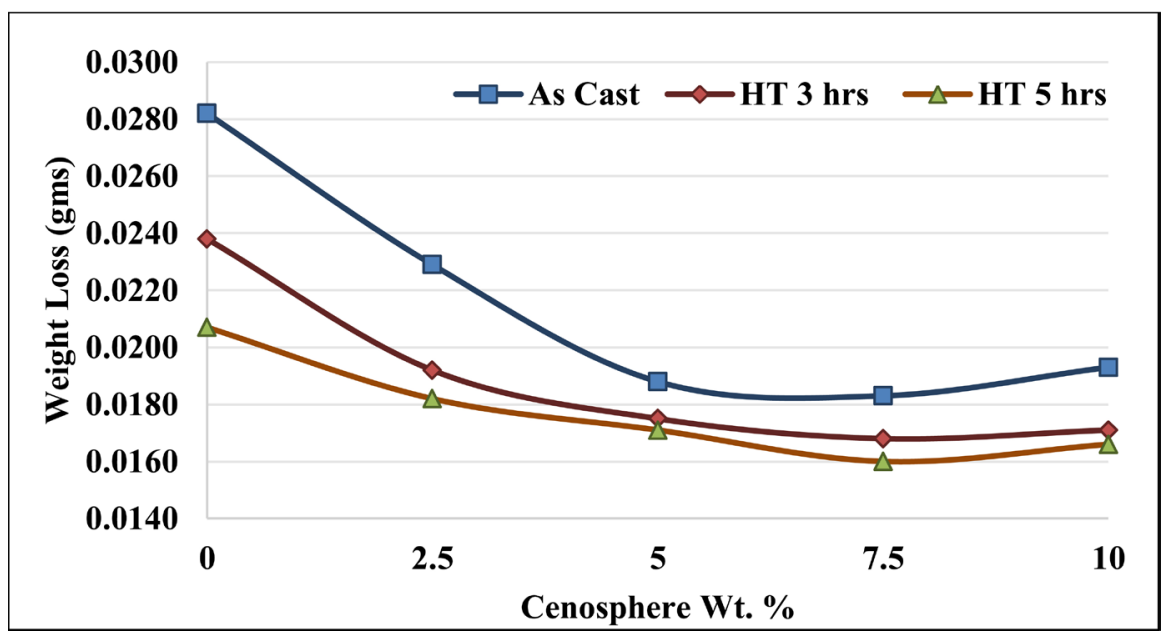

Figure 11. Variation of weight loss as a result corrosion observed after 30 days with varied cenosphere percent on $\mathrm{NaCl}$. 
loss up to $7.5 \%$ reinforcement, further the weight loss were found negligible with Al 7075 MMCs containing varied \% hollow sphere on an immersion in the $\mathrm{NaCl}$ solution for 30 days. From, Figure 11, it can also be concluded that the duration of solution heat treatment of Al 7075 MMCs containing varied \% hollow sphere resulted with increased corrosion resistance.

Figures 12-15 present the weight loss and rate of corrosion diagrams for the as-cast and solutionized samples immersed in $0.1 \mathrm{M} \mathrm{NaOH}$ solution. The immersion corrosion test on the $0.1 \mathrm{M} \mathrm{NaOH}$ solution is carried out between 12 to 96 hours with interval of 12 hours. Furthermore, the solution heat-treated composite specimens showed an improved corrosion resistance irrespective of the percent reinforcement. The grain boundary precipitation occurs at higher temperature due to which the continuous anodic channel braking attributed to the increased corrosion resistance. The weight lost by the samples subjected to the immersion corrosion test of Al7075 MMCs containing varied \% hollow sphere and the unreinforced alloy did not follow a consistency.

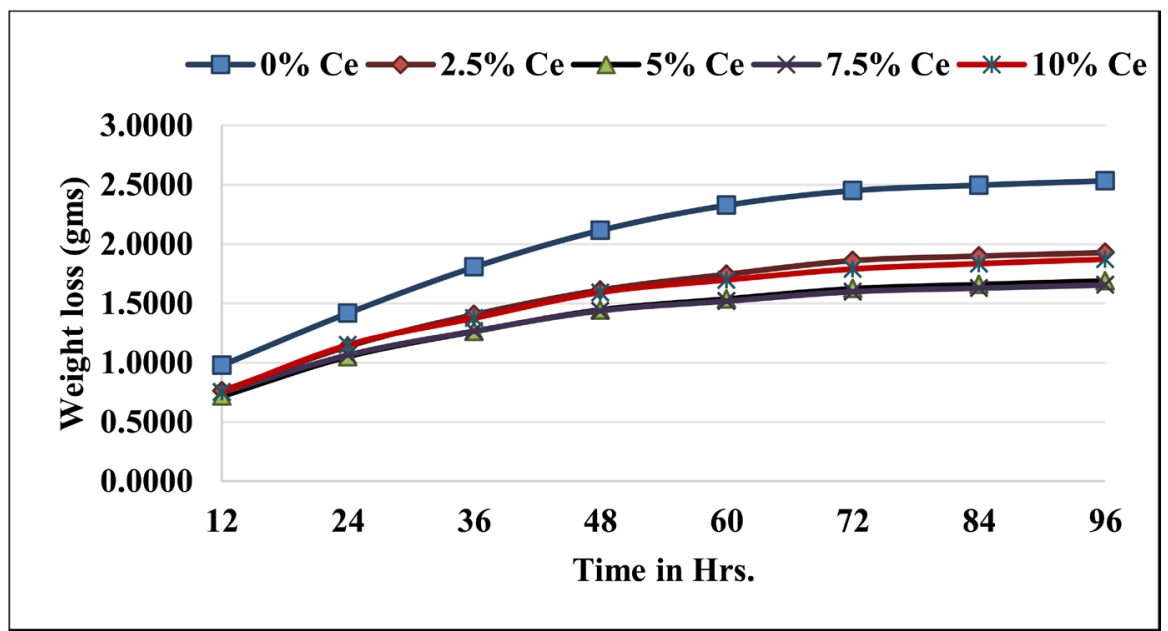

Figure 12. Immersion corrosion test results of as cast samples of composites on $\mathrm{NaOH}$.

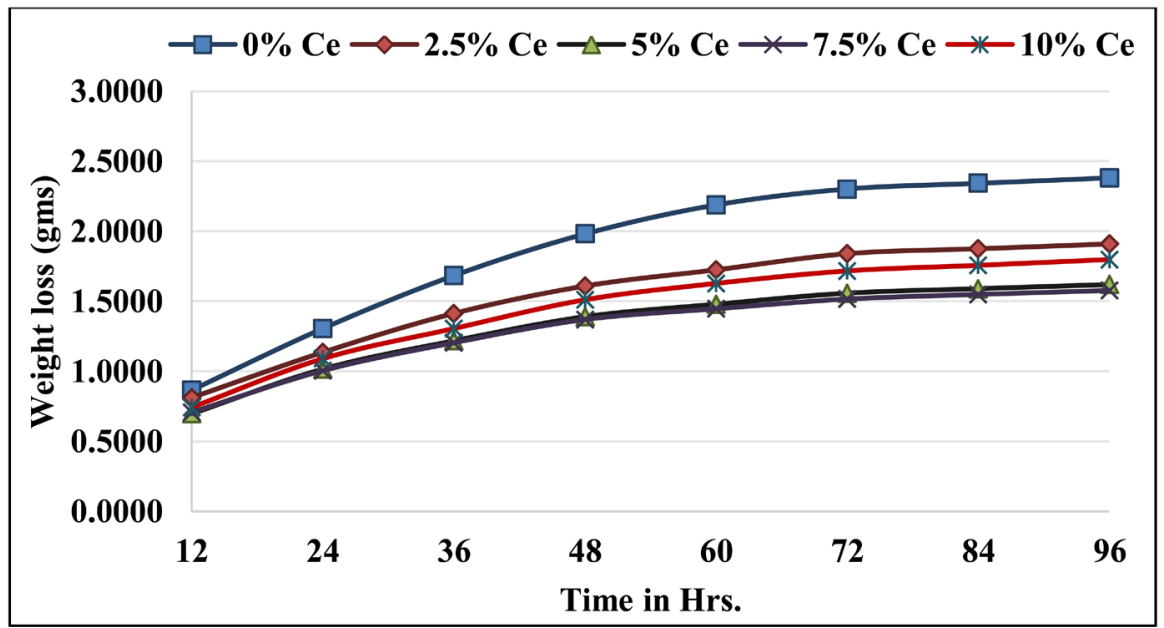

Figure 13. Immersion corrosion test results of 3 hours solution heat treated samples of composites on $\mathrm{NaOH}$. 


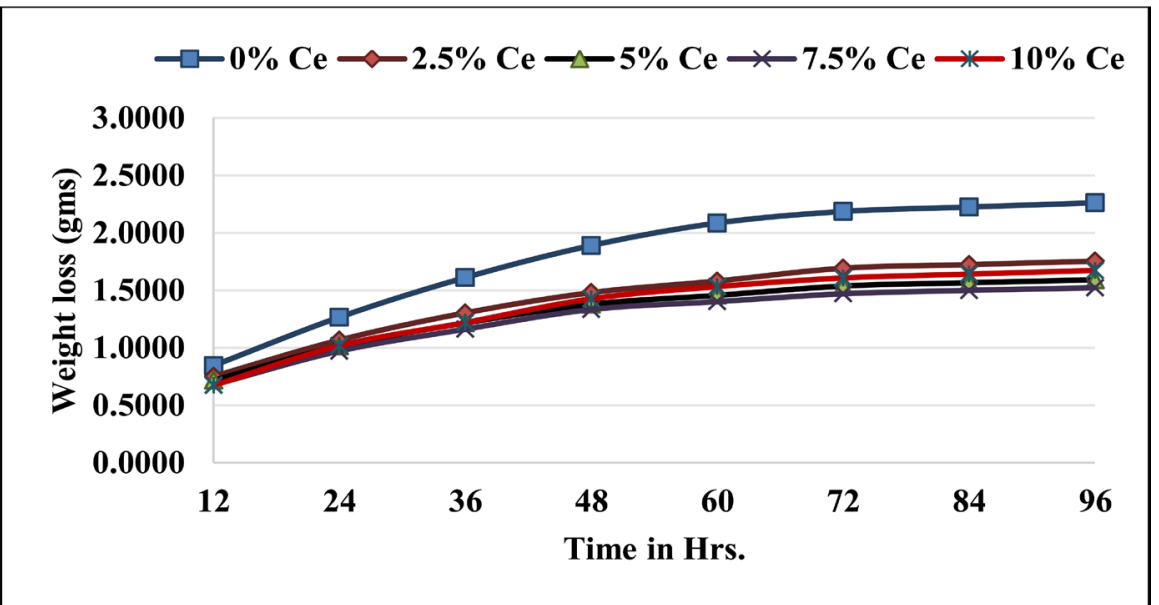

Figure 14. Immersion corrosion test results of 5 hours solution heat treated samples of composites on $\mathrm{NaOH}$.

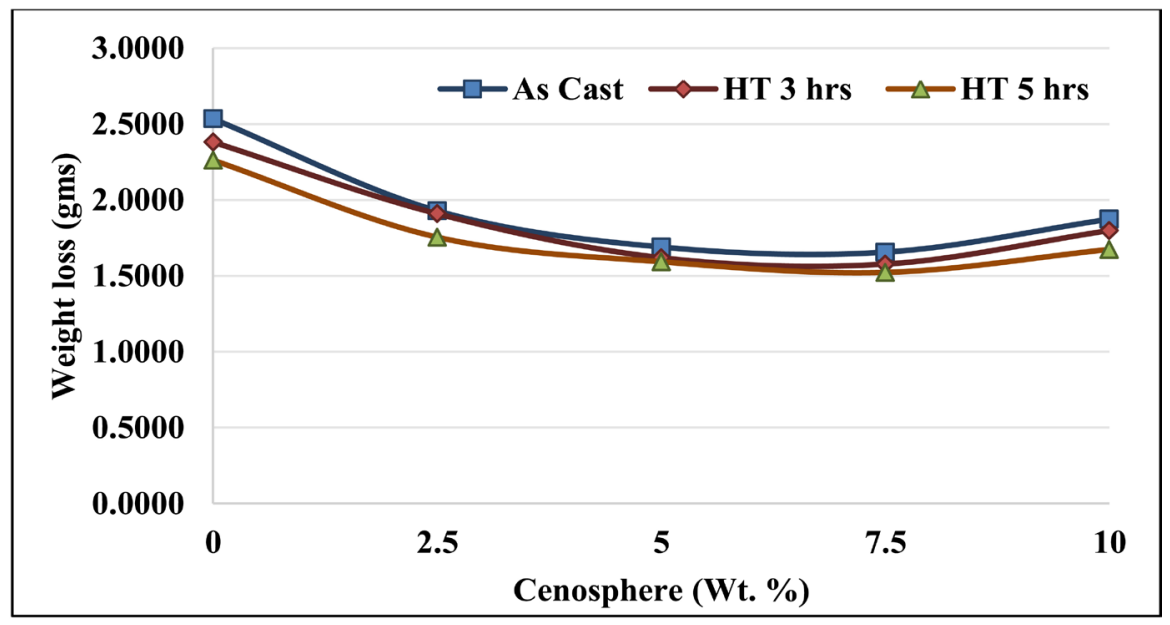

Figure 15. Variation of weight loss with varied cenosphere percent on $\mathrm{NaOH}$.

\subsection{SEM Analysis of Corroded Samples}

Figures 16(a)-(c), SEM microphotographs of Al7075-cenosphere composite after salt spray type corrosion test. From SEM images, the corroded parts can be seen as micro cracks after exposing the material to salt spray type corrosion test. Figures 17(a)-(c), SEM microphotographs of composite material containing varied percent cenosphere after immersion corrosion test on 5\% NaCl. From SEM images, the corroded parts can be seen as micro cracks and pitting after exposing the material to immersion corrosion test. Figures 18(a)-(c), SEM microphotographs of the composite material containing varied percent cenosphere after immersion corrosion test on $0.1 \mathrm{M} \mathrm{NaOH}$ solution. From SEM images, the corroded parts can be seen as micro cracks and pitting after exposing the material to immersion corrosion test.

\section{Conclusions}

The following conclusions were drawn from the experimental study. 


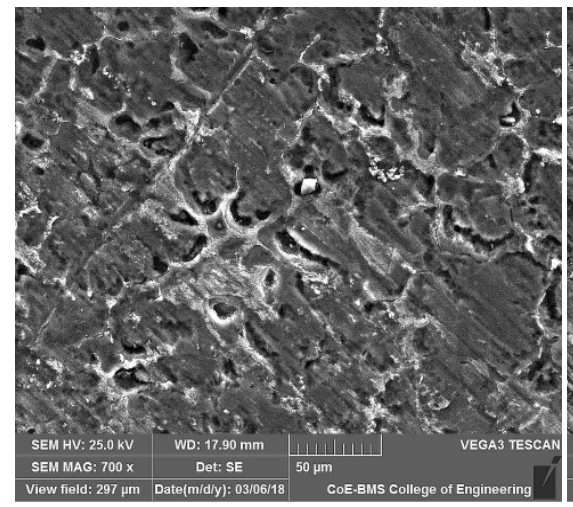

(a)

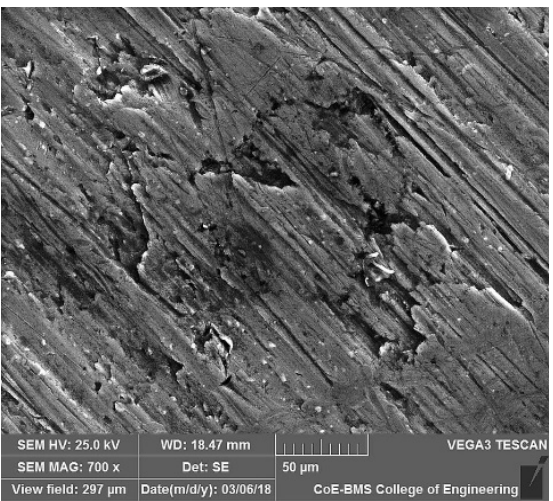

(b)

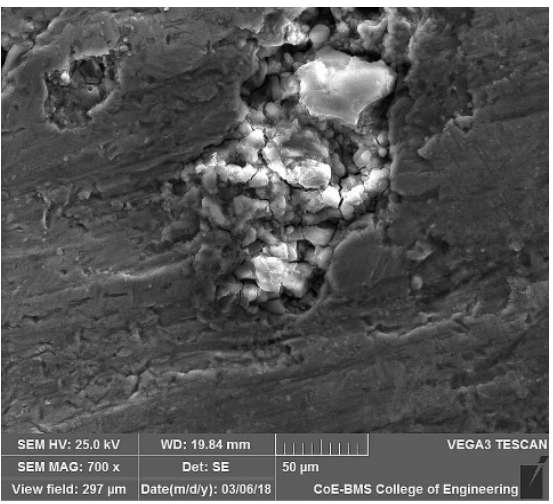

(c)

Figure 16. SEM images of Al7075-cenosphere samples subjected to salt spray corrosion test. (a) $0 \%$ Cenosphere, (b) $5 \%$ Cenosphere, (c) $10 \%$ Cenosphere.

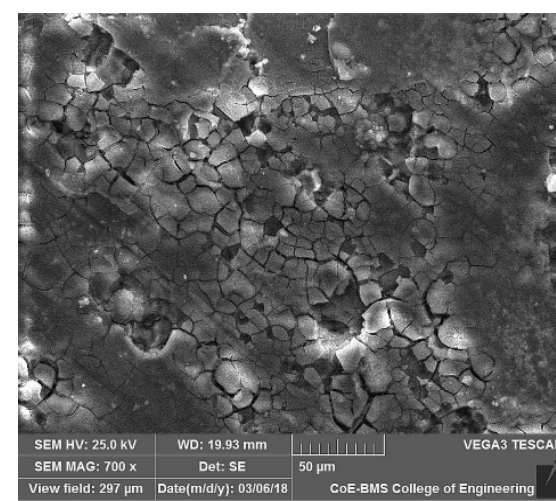

(a)

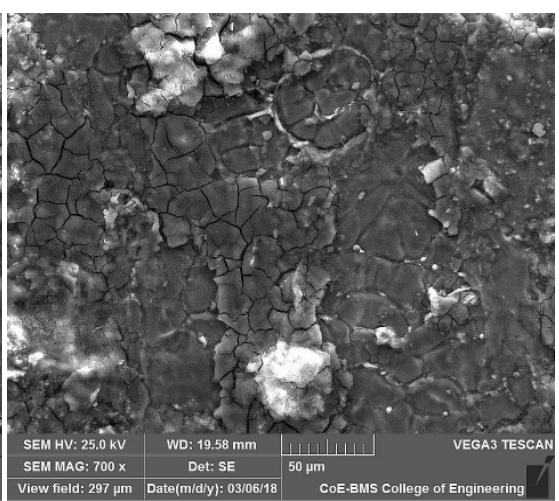

(b)

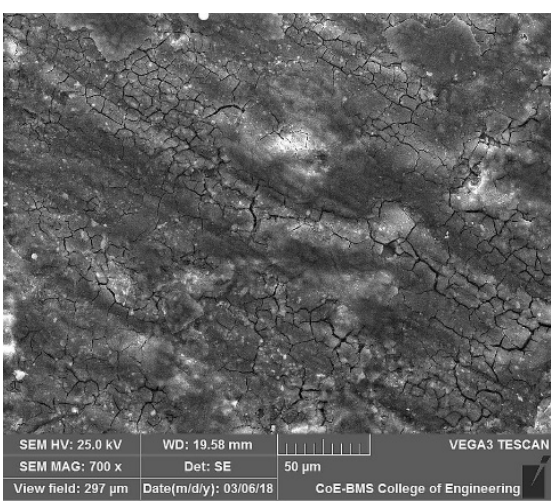

(c)

Figure 17. SEM images of Al7075-cenosphere samples subjected to $5 \% \mathrm{NaCl}$ immersion corrosion test. (a) $0 \%$ Cenosphere, (b) $5 \%$ Cenosphere, (c) $10 \%$ Cenosphere.

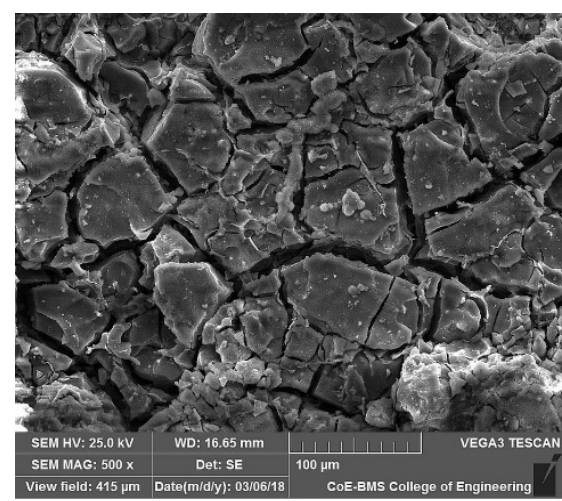

(a)

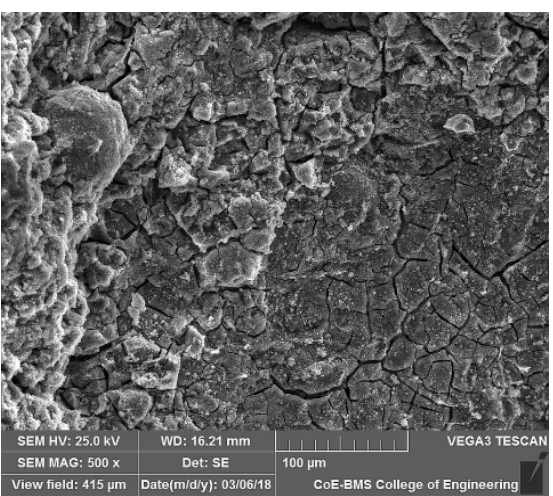

(b)

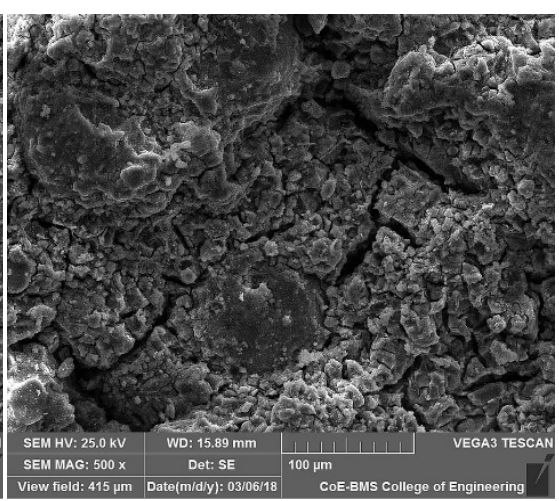

(c)

Figure 18. SEM images of Al7075-cenosphere samples subjected to $0.1 \mathrm{M} \mathrm{NaOH}$ immersion corrosion test. (a) $0 \%$ Cenosphere, (b) $5 \%$ Cenosphere, (c) $10 \%$ Cenosphere.

- Corrosion resistance increases with increase in wt\% of cenosphere; however, when the Al 7075 grade aluminum metal matrix composite specimens containing reinforcement greater than $7.5 \%$ cenosphere, the reduction in corro- 
sion resistance was observed during salt spray type corrosion test.

- Weight loss of specimen decreased with increase in wt\% of cenosphere when exposed to $\mathrm{NaOH}$ media.

- Increase of corrosion rate was observed with an increase of exposure duration on salt spray type corrosion test and immersion corrosion test.

- Solution heat treated Al7075 grade aluminum metal matrix composite specimens exhibited an improved corrosion resistance irrespective of percent reinforcement.

- The heat treatment duration was significant on corrosion resistance of aluminum metal matrix composite specimens. Higher heat treatment duration showed an improved corrosion resistance.

- SEM microphotographs of Al7075 grade aluminum metal matrix composite specimens containing varied percent cenosphere, exposed to salt spray type corrosion test and immersion corrosion tests exhibited pitting corrosion and micro cracks due to corrosion.

- The improvement in corrosion resistance of Al7075 grade aluminum metal matrix composite specimens containing varied percent cenosphere, may be due to formation of sodium hydrochloride layer on the specimen surface which acts as the protective layer and inhibits corrosion, during salt spray and immersion corrosion tests.

- Hence the thickness of protective layer formed on the Al7075 aluminum grade composites which inhibits corrosion can be studied further.

\section{References}

[1] Tzamtzis, S., Barekar, N.S., Hari Babu, N., Patel, J. and Dhindaw, B.K. (2009) Processing of Advanced $\mathrm{Al} / \mathrm{SiC}$ Particulate Metal Matrix Composites under Intensive Shearing-A Novel Rheo-Process. Composites: Part A, 40, 144-151. https://doi.org/10.1016/j.compositesa.2008.10.017

[2] Singla, M., Deepak Dwivedi, D., Singh, L. and Chawla, V. (2009) Development of Aluminium Based Silicon Carbide Particulate Metal Matrix Composite. Journal of Minerals and Material Characterisation and Engineering, 8, 455-467. https://doi.org/10.4236/jmmce.2009.86040

[3] Mahendra, K.V. and Radhakrishna, K. (2007) Fabrication of Al-4.5\% Cu Alloy with Fly Ash Metal Matrix Composites and Its Characterization. Materials Science-Poland, 25, 57-68.

[4] Pawar, P.B. and Utpat, A.A. (2014) Development of Aluminium Based Silicon Carbide Particulate Metal Matrix Composite for Spur Gear. Procedia Materials Science 6, 1150-1156. https://doi.org/10.1016/j.mspro.2014.07.187

[5] Sozhamannan, G.G., Balasivanandhaprabu, S. and Venkatagalapathy, V.S.K. (2012) Effect of Proceessing Parameters on Metal Matrix Composites: Stir Casting Process. Journal of Surface Engineered Materials and advanced technology, 2, 11-15. https://doi.org/10.4236/jsemat.2012.21002

[6] Balasivanandha Prabu, S., Karunamoorthy, L., Kathiresan, S. and Mohan, B. (2006) Influence of Stirring Speed and Stirring Time on Distribution of Particles in Cast Metal Matrix Composite. Journal of Material Processing Technology, 171, 268-273. https://doi.org/10.1016/j.jmatprotec.2005.06.071 
[7] Naher, S., Brabazon, D. and Looney, L. (2003) Similation of the Stir Casting Process. Journal of Material Processing Technology, 143-144, 567-571. https://doi.org/10.1016/S0924-0136(03)00368-6

[8] Bharat, V., Durga Prasad, B. and Venkateswarlu, K. (2017) Effect of Beryllium Aluminum Cyclosilicate on Thermal Expansion Behavior of Al-Based Composites. Journal of Minerals and Materials Characteriszation and Engineering, 5, 140-152. https://doi.org/10.4236/jmmce.2017.53012

[9] Ravi Kumar, D.V., Viswanath, N. and Prashanth, T. (2013) Adhesive Wear Behaviour of Aluminium 7075 Cenosphere Composites. Journal of Manufacturing Engineering, 8, 192-195.

[10] Prakash Rao, C.R., Poornachandra, Kiran, R. and Asha, P.B. (2016) Influence of Machining Parameters on Cutting Tool Life While Machining Aluminum Alloy Fly Ash Composite. IOP Conf. Series: Materials Science and Engineering, 149, Article ID: 012157. https://doi.org/10.1088/1757-899X/149/1/012157

[11] Ravi Kumar, V., Suresh, R. and Prashanth, T. (2013) Corrosion Behaviour of Eutectic Aluminium Cenosphere Composites. Journal of Manufacturing Engineering, 8 , 175-177.

[12] Pinto, G.M., Nayak, J. and Nityananda Shetty, A. (2009) Corrosion Behaviour of $6061 \mathrm{Al}-15 \mathrm{vol}$. Pct. SiC Composite and Its Base Alloy in a Mixture of 1:1 Hydrochloric and Sulphuric Acid Medium. International Journal of Electrochemical Science, 4, 1452-1468.

[13] Escalera-Lozano, R., Gutiérrez, C.A., Pech-Canul, M.A. and Pech-Canul, M.I. (2007) Corrosion Characteristics of Hybrid Al/SiCp/ $\mathrm{MgAl}_{2} \mathrm{O}_{4}$ Composites Fabricated with Fly Ash and Recycled Aluminum. Materials Characterization, 58, 953-960. https://doi.org/10.1016/j.matchar.2006.09.012

[14] Madakson, P.B., Malik, I.A., Laminu, S.K. and Bashir, I.G. (2012) Effect of Anodization on the Corrosion Behavior of Aluminium Alloy in $\mathrm{HCl}$ Acid and $\mathrm{NaOH}$. International Journal of Materials Engineering, 2, 38-42. https://doi.org/10.5923/j.ijme.20120204.02

[15] Osório, W.R., Cheung, N., Peixoto, L.C. and Garcia, A. (2009) Corrosion Resistance and Mechanical Properties of an $\mathrm{Al} 9 \mathrm{wt} \% \mathrm{Si}$ Alloy Treated by Laser Surface Remelting. International Journal of Electrochemical Science, 4, 820-831.

[16] Zupanc, U. and Grum, J. (2010) Effect of Pitting Corrosion on Fatigue Performance of Shot-Peened Aluminium 7075-T651. Journal of Materials Processing Technology, 210, 1197-1202. https://doi.org/10.1016/j.jmatprotec.2010.03.004

[17] Sun, S., Zheng, Q., Li, D. and Wen, J. (2009) Long-Term Atmospheric Corrosion Behaviour of Aluminium Alloys 2024 and 7075 in Urban, Coastal and Industrial Environments. Corrosion Science, 51, 719-727.

https://doi.org/10.1016/j.corsci.2009.01.016

[18] Nunes, P.C.R. and Ramanathan, L.V. (1995) Corrosion Behaviour of Alumina-Aluminium and SiC-Aluminium Metal Matrix Composites. Corrosion, 51, 610-617. https://doi.org/10.5006/1.3293621

[19] Bobic, B., Miitrovic, S., Babic, M. and Bobic, I. (2009) Corrosion of Aluminium and Zinc-Aluminium Alloys Based Metal-Matrix Composites. Tribology in Industry, 31, 44-53.

[20] Li, J., Peng, Z., Li, C., Jia, Z., Chen, W. and Zheng, Z. (2008) Mechanical Properties, Corrosion Behaviors and Microstructures of 7075 Aluminium Alloy with Various Aging Treatments. Transactions of Nonferrous Metals Society of China, 18, 755-762. https://doi.org/10.1016/S1003-6326(08)60130-2 
[21] Bienias, J., Walczak, M., Surowska, B. and Sobczak, J. (2003) Microstructure and Corrosion Behavior of Aluminium Fly Ash Composites. Journal of Optoelectronics and Advanced Materials, 5, 493-502.

[22] Ramachandra, M. and Radhakrishna, K. (2005) Microstructure, Mechanical Properties, Wear and Corrosion Behavior of Al-SiCp/Fly Ash Composite. Materials Science and Technology, 21, 1337-1343. https://doi.org/10.1179/174328405X69533

[23] Necsulescu, D.A. (2011) The Effects of Corrosion on the Mechanical Properties of Aluminium Alloy 7075-T6. UPB Scientific Bulletin, Series B, 73, 223-229.

[24] Ramchandra, M. and Radhakrishna, K. (2007) Effect of Reinforcement of Fly Ash on Sliding Wear, Slurry Erosive Wear and Corrosive Behavior of Aluminium Matrix Composite. Wear, 262, 1450-1462. https://doi.org/10.1016/j.wear.2007.01.026 